\title{
Effect of heat treatment and packaging systems on the stability of fish sausage
}

\author{
Bruna Rafaela Dallabona1, Laura Beatriz Karam¹, Roberta Wagner', Dayse Aline Ferreira Silva \\ Bartolomeu $^{2}$, Jorge Daniel Mikos ${ }^{1}$, João Gabriel Phabiano Francisco ${ }^{1}$, Renata Ernlund Freitas \\ de Macedo ${ }^{1}$, Peter Gaberz Kirschnik ${ }^{1}$
}

\footnotetext{
${ }^{1}$ Programa de Mestrado em Ciência Animal, Escola de Ciências Agrárias e Medicina Veterinária, Pontifícia Universidade Católica do Paraná, São José dos Pinhais, PR, Brasil.

${ }^{2}$ Programa de Mestrado em Tecnologia de Alimentos, Universidade Federal do Paraná, Curitiba, PR, Brasil.
}

\begin{abstract}
The purpose of this study was to evaluate the physicochemical and microbiological stability of sausages produced from mechanically separated fish meat (MSM) obtained from Nile tilapia filleting residues. Different heat treatments (pasteurization or smoking) and packaging systems (conventional or vacuum) were used. The sausages were characterized for chemical composition, weight loss, water activity, instrumental texture and sensorial analysis. Additionally, microbiological analysis, instrumental color, $\mathrm{pH}$, thiobarbituric acid reactive substances (TBARS) and total volatile base nitrogen (TVB-N) were assessed during storage. No presence of Escherichia coli, Salmonella sp. or coagulase-positive Staphylococcus was detected; however, the psychrotrophic count in pasteurized sausages exceeded the limits allowed for consumption. $\mathrm{pH}$ and lipid oxidation speed (TBARS) values were reduced when vacuum packaging was used. Volatile nitrogenous bases remained virtually constant during the storage period, and higher values were observed in smoked products. Pasteurized sausages remain stable for 10 and 15 days in conventional and vacuum packages, respectively, and smoked sausages remain stable for 25 and 45 days in conventional and vacuum packages, respectively.
\end{abstract}

Key Words: mechanically separated meat, Oreochromis niloticus, pasteurization, smoking, storage

\section{Introduction}

Aquaculture has been considered as the future source of high quality proteins, due to its increased growth as a productive activity and opportunity for income generation. Therefore, the study of species must be prioritized for improved animal performance and enhanced technologies, which contribute to the development of the fish processing industry (Bombardelli et al., 2005; Silva et al., 2009).

The national aquaculture is essentially based on the production chain of tilapia and marine shrimp (Scorvo Filho et al., 2010). One reason for Nile tilapia (Oreochromis niloticus) cultivation is the high appreciation of consumers for its meat, which is white, presenting a delicate flavor and absence of spines, in a "Y" shape (Kubitza, 2000). However, the processing of tilapia for the production of fillets generates a high amount of residues (viscera, head, skin, scales, carcass with attached meat, trimmings) that varies from 65 to $70 \%$ of the total processed volume. Nevertheless, resulting carcasses can be processed to originate mechanically separated fish meat (MSM), which, after a sequence of washes, can be used for the production of surimi or directly utilized as an ingredient of processed products (Kubitza \& Campos, 2006; Neiva, 2006; BiscalchinGrischek et al., 2003).

Other studies have used MSM originating from whole, eviscerated tilapia or carcass in the production of goods like sausages (Oliveira Filho et al., 2010b; Oliveira Filho et al., 2012), nuggets (Kirschnik et al., 2007) mortadella (Moreira et al., 2008), fishburgers (Marengoni et al., 2009; Sary et al., 2009; Mello et al., 2012; Fogaça et al., 2013), pâté (Minozzo et al., 2008) and croquette (Bordignon et al., 2010).

Embedded goods are industrialized products of animal origin in high consumer demand. Following the trends of red-meat and poultry processing industries, known to make excellent use of raw materials by transforming them in a variety of products, the Brazilian fish industry must innovate and invest in the development of products that increase fish consumption in the country and reduce the amount of residues (Moreira et al., 2008; Parmigiani, 2010).

The purpose of this study was to elaborate sausages from MSM obtained from tilapia carcasses using two types of thermal processing - pasteurization and smoking -, and to evaluate their physicochemical and sensorial characteristics as well as oxidative, colorimetric and microbiological 
stability during storage at $5{ }^{\circ} \mathrm{C}$ when two packaging systems, conventional and vacuum, were used.

\section{Material and Methods}

One hundred kilograms (100 kg) of Nile tilapia carcasses (Oreochromis niloticus) were provided by COPISCES (Cooperativa Agroindustrial de Piscicultura Pisces), a Fish Agricultural Cooperative, located in ToledoPR, Brazil, in April 2010. In the processing unit, the tilapias were eviscerated, beheaded and filleted, and the carcasses resulting from this process were washed with chlorinated water. The extraction of MSM was performed with a HT-500 pulper machine $\left(\right.$ High Tech $\left.^{\circledR}\right)$. Afterwards, $0.1 \%$ sodium erythorbate and $0.5 \%$ sodium tripolyphosphate were added to the MSM, which was then homogenized. The MSM $(13 \mathrm{~kg})$ was packaged in polyethylene bags in portions of around $500 \mathrm{~g}$, frozen and transported to the Aquaculture Research Laboratory at PUCPR, where it was stored at $-18^{\circ} \mathrm{C}$ until further use (after approximately 20 days).

The ingredients used in the sausage formulations were: tilapia fillets and MSM, fresh pork fat (Frigorífico Juliatto), salt $\left(\right.$ Diana $\left.^{\circledR}\right)$, sugar $\left(\right.$ União $\left.^{\circledR}\right)$, textured soy protein (Mais Vita $^{\circledR}$ ), monosodium glutamate $\left(\right.$ Ajinomoto $^{\circledR}$ ), cassava starch $\left(\right.$ Zaeli $\left.^{\circledR}\right)$, dehydrated onion $\left(\right.$ Kitano $\left.^{\circledR}\right)$, dehydrated garlic $\left(\right.$ Kitano $\left.^{\circledR}\right)$, white and black pepper $\left(\mathrm{Kitano}^{\circledR}\right)$ and dehydrated parsley $\left(\mathrm{Kitano}^{\circledR}\right)$. Subsequently, the sausages were subjected to different thermal treatments: pasteurization by steam cooking (treatment 1 ) and hot smoking (treatment 2 ). Treatment 1 was performed with $9 \mathrm{~kg}$ of sausages (average weight of $70 \mathrm{~g}$ each sausage), steam-pasteurized at $70{ }^{\circ} \mathrm{C}$ for 30 minutes, followed by further baking at $85{ }^{\circ} \mathrm{C}$ for 40 minutes in an oven $\left(\right.$ Incomaf $\left.^{\circledR}\right)$. Treatment 2 was performed with $9 \mathrm{~kg}$ of sausages (average weight of $70 \mathrm{~g}$ each sausage) pre-dried in an oven (Nova Ética ${ }^{\circledR}$ ) at $50{ }^{\circ} \mathrm{C}$ for 40 minutes (with air circulation) and hot-smoked in a small smoker $\left(\right.$ Poly-Térmica ${ }^{\circledR}$ ). The distance between the samples and the sawdust was 1 meter, and the smoking process lasted 3 hours, at an average temperature of $100{ }^{\circ} \mathrm{C}$. In both thermal treatments, the inner temperature of the sausages exceeded $72{ }^{\circ} \mathrm{C}$, for at least 15 seconds.

The smoke aroma powder (Duas Rodas ${ }^{\circledR}$ ) was added only in the formulation of sausages that were subjected to the cooking process (Table 1).

The raw materials (MSM and tilapia fillets) were thawed for 24 hours at $7{ }^{\circ} \mathrm{C}$. The fillets were minced in an electric grinder (Bermar ${ }^{\circledR}$ BM02). The MSM, the fillet and the remaining ingredients were weighed and manually homogenized in a plastic tray for 10 minutes. Subsequently, the dough was embedded with a manual stuffer (EJ8, Jamar ${ }^{\circledR}$ ) in natural sheep casings previously treated with $4 \%$ acetic acid solution for 20 minutes. The final product was manually tied with cotton thread at every $15 \mathrm{~cm}$.

After thermal treatments and subsequent cooling, the pasteurized and smoked sausages were either vacuum- or conventionally packaged in portions of $100 \mathrm{~g}$. Vacuumpackaging was performed in polyethylene bags with an EVOH barrier layer (high barrier) using the packing machine Selovac ${ }^{\circledR} 200 B$. Conventional packaging was performed in polystyrene trays wrapped with a clear plastic film (polyvinyl chloride (PVC) film). Pasteurized and smoked sausages, conventionally and vacuum-packaged, were stored at $5{ }^{\circ} \mathrm{C}$ in a B.O.D. incubator (ACB Labor ${ }^{\mathbb{R}}$ ) for a pre-determined period of time for each treatment. The product characterization after production (time 0 ) included physicochemical and sensorial analyses.

Centesimal composition analysis (moisture, protein, lipids, ashes and carbohydrates) of raw material and products (sausages) was performed according to analytical methods described by the Association of Official Analytical Chemistry (AOAC, 2002). Moisture, through the gravimetric method, at $105{ }^{\circ} \mathrm{C}$; protein, through the Micro Kjeldahl method; lipids, through the Soxhlet extraction method; ash, through the incineration method, in a muffle furnace at $550{ }^{\circ} \mathrm{C}$; and carbohydrates, calculated by difference to $100 \%$. pH was measured using the $\mathrm{pH}$ meter HOMIS ${ }^{\circledR}$, with an insertion electrode (model SC18) positioned inside the sausages (AOAC, 2002). Weight loss during storage was obtained as the difference (\%) between the final weight (after storage period) and the initial weight (time 0) (AOAC, 2002). The lipid oxidation analysis was performed through the thiobarbituric acid reactive substances (TBARS) method, according to Vyncke (1970), and total volatile base nitrogen (TVB-N) was analyzed as reported by Howgate (1976), in

Table 1 - Formulation of sausages made from MSM of Nile tilapia filleting residue

\begin{tabular}{lcc}
\hline \multirow{2}{*}{ Ingredients } & Treatment 1 & Treatment 2 \\
\cline { 2 - 3 } & Amount (\%) & Amount (\%) \\
\hline Mechanically separated fish meat & 64.08 & 64.45 \\
Fillet & 22.52 & 22.65 \\
Pork fat & 5.00 & 5.00 \\
Salt & 1.60 & 1.60 \\
Sugar & 0.30 & 0.30 \\
Textured soy protein & 2.00 & 2.00 \\
Monosodium glutamate & 0.50 & 0.50 \\
Cassava starch & 3.00 & 3.00 \\
Dehydrated onion & 0.16 & 0.16 \\
Dehydrated garlic & 0.16 & 0.16 \\
White and black pepper & 0.09 & 0.09 \\
Dehydrated parsley & 0.09 & 0.09 \\
Smoke aroma powder & 0.50 & - \\
\hline
\end{tabular}

MSM - mechanically separated fish meat. 
a method that determines the concentration of ammonia, trimethylamine and dimethylamine.

Sausages were sensory-evaluated through the acceptance test for the attributes color, aroma, flavor, texture and general acceptance, using the Nine Point Hedonic Scale. Tests of purchase and consumption intention were also performed. Sensorial tests were completed by 52 non-trained panelists using the method described by Dutcosky (2011). In order to evaluate weight loss, sausages were weighed before and after the thermal process to which they were subjected, thus obtaining the initial and final weight values, as well as the percentage of weight loss. Water activity was determined with the equipment Aqualab ${ }^{\circledR} \mathrm{CX}-2$ (Decagon Devices ${ }^{\circledR}$ ) at $20{ }^{\circ} \mathrm{C}$. Sausage instrumental hardness analysis was performed with a texturometer (TA-XT2 $i$, Stable Micro System $^{\circledR}$ ) previously calibrated with a standard weight of $5 \mathrm{~kg}$. Samples were cut in slices of $1.5 \mathrm{~cm}(15 \mathrm{~mm})$ and compressed by an aluminum cylindrical probe $(\mathrm{P} / 36 \mathrm{R})$. The pre-test speed was $2.0 \mathrm{~mm} / \mathrm{s}$; the test speed, $1.0 \mathrm{~mm} / \mathrm{s}$, and the post-test speed, $2.0 \mathrm{~mm} / \mathrm{s}$, and the distance from the platform was $5.0 \mathrm{~mm}$, in accordance with Bourne (2002).

Product physicochemical and microbiological stability analysis was performed in samples collected at $0,5,10$, $15,20,25,30,35,40$ and 45 days of storage. Instrumental color was determined with the use of a portable colorimeter (Chroma Meter CR-410, Konica Minolta ${ }^{\circledR}$ ) operating with light source $\mathrm{C}$ and using the color space: $\mathrm{L}^{*}$ (luminosity), a* (red - green intensity) and b* (yellow - blue intensity), according to CIE (1986). The microbiological development was evaluated through the total count of psychotropic aerobic microorganisms and coagulase-positive Staphylococcus by the spread plate method; detection of Salmonella sp., and Escherichia coli count, by the Petrifilm ${ }^{\circledR}$ method (Brasil, 2003).

The study was conducted in a completely randomized design with four treatments (smoked sausages in conventional packaging, pasteurized sausages in conventional packaging, smoked sausages in vacuum packaging and pasteurized sausages in vacuum packaging) and three replicates, in a total of $4.5 \mathrm{~kg}$ each treatment. Data were analyzed by
ANOVA and means were compared by the Tukey test at a $5 \%$ probability level, during storage and among treatments until day 25. From day 30 to the end of the storage time, only vacuum-packaged sausages were evaluated. A completely randomized design with two treatments (smoked and pasteurized vacuum-packaged sausages) and three replicates was used, and means were compared by the $\mathrm{t}$ test at a 5\% probability level. All analyses were performed using the statistical software Graph Pad Prism, version 3.0, for Windows.

\section{Results and Discussion}

The centesimal composition demonstrated that the values obtained from lipids in this study were higher when compared with those found by other authors (Table 2). Oliveira Filho et al. (2010b) verified the presence of $78.85 \%$ moisture, $18.74 \%$ protein, $1.28 \%$ lipids and $1.05 \%$ ash for tilapia fillets and $75.47 \%$ moisture, $12.76 \%$ protein, $10.54 \%$ lipids and $1.14 \%$ ash for MSM from tilapia carcasses. Averages of $79.83 \%$ moisture, $15.13 \%$ protein, $2.91 \%$ lipids and $1.35 \%$ ash were found by Kirschnik \& MacedoViegas (2009) for MSM from tilapia carcasses. According to Ogawa \& Maia (1999), the lipid composition of fish and its products depends on the species, age, gender, size and processing method, among other factors.

Smoked sausages presented the lowest percentage of moisture due to water loss resulting from the smoking process; high protein and lipid contents were found due to the inverse relationship between moisture and lipid content as well as moisture and protein (Ogawa \& Maia, 1999; Minozzo et al., 2004; Minozzo et al., 2008). There was no difference in the protein, lipid and ash contents $(\mathrm{P}>0.05)$ between treatments (pasteurized and smoked sausages).

The addition of condiments, mainly salt, was responsible for a significant increase $(\mathrm{P}<0.05)$ in the ash content in sausages compared with raw materials, corroborating results observed by Souza et al. (2004). Other ingredients, such as starch, accounted for an increase in the carbohydrate content.

Table 2 - Centesimal composition of MSM, tilapia fillet, raw sausage, and smoked and pasteurized sausages made with MSM from tilapia filleting residues $(\%)$

\begin{tabular}{|c|c|c|c|c|c|}
\hline Sample & Moisture & Protein & Lipids & Ash & Carbohydrates \\
\hline Mechanically separated fish meat & $71.00 \pm 0.5$ & $11.96 \pm 0.5(41.24 b)$ & $15.37 \pm 0.3(53.00 \mathrm{a})$ & $1.22 \pm 0.1(4.21 \mathrm{c})$ & $0.45 \pm 1.0(1.55)$ \\
\hline Tilapia fillet & $78.80 \pm 0.1$ & $16.30 \pm 0.2(76.88 \mathrm{a})$ & $3.26 \pm 0.2(15.38 \mathrm{~d})$ & $0.96 \pm 0.01(4.53 c)$ & $0.68 \pm 0.2(3.21)$ \\
\hline Raw sausage & $64.98 \pm 1.3$ & $13.73 \pm 0.3(39.21 \mathrm{c})$ & $14.87 \pm 0.4(42.46 b)$ & $2.91 \pm 0.1(8.31 b)$ & $3.51 \pm 1.5(10.02)$ \\
\hline Pasteurized sausage & $61.18 \pm 1.2$ & $16.45 \pm 0.2(42.37 b)$ & $14.38 \pm 0.4(37.05 \mathrm{c})$ & $3.44 \pm 0.04(8.86 a)$ & $4.55 \pm 0.6(11.72)$ \\
\hline Smoked sausage & $54.26 \pm 0.4$ & $19.30 \pm 0.3(42.19 b)$ & $17.74 \pm 0.5(38.78 b c)$ & $3.97 \pm 0.1(8.69 a)$ & $4.73 \pm 0.8(10.34)$ \\
\hline
\end{tabular}

Values between parentheses were calculated on a dry basis $(\%)$.

All means from the same parameters located in the same columns, followed by lowercase letters, differ significantly according to the Tukey test ( $<<0.05)$. MSM - mechanically separated fish meat. 
The sensory analysis of smoked and pasteurized sausages revealed significant differences $(\mathrm{P}<0.05)$ on attributes such as color and aroma. Smoked sausages were better accepted, averaging 7.3 for color and 7.5 for aroma, while pasteurized sausages averaged 6.3 and 6.9, respectively (Figure 1).

When grouped, the averages of attributes added up 7.5 for smoked sausage and 7.1 for pasteurized sausage. Thus, no significant difference $(\mathrm{P}>0.05)$ between either treatments regarding flavor, texture and global acceptance was found at a 5\% level. Both values remained between points 7 and 8 of the Nine Point Hedonic Scale, corresponding to "like moderately" and "like very much", respectively. These results showed that both products were well accepted by panelists, although a higher appreciation for color and aroma of smoked samples was observed, probably due to an enhancement of these attributes caused by the smoking process.

Moreira et al. (2008) obtained low acceptance with tilapia mortadella containing vegetal fat compared with the products formulated in this study, averaging 5.0 for appearance, 5.3 for flavor, 5.4 for aroma, 4.9 for color and 4.8 for texture.

The analysis of consumption and purchase intention revealed that $86.8 \%$ of 52 panelists would consume smoked sausages and $79.2 \%$ would buy them. Regarding pasteurized sausages, consumption intention was declared by $83 \%$ of samplers and purchase intention, by $71.2 \%$. These results, for both products, demonstrate the interest from possible consumers. In the study of Moreira et al. (2008),

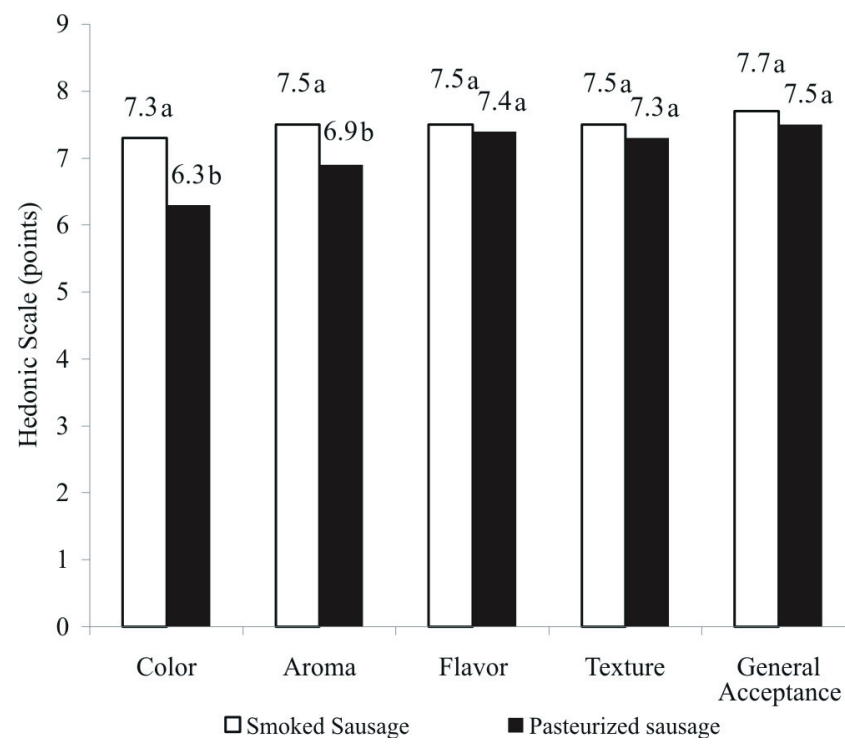

MSM - mechanically separated fish meat.

Figure 1 - Average scores attributed to sausages made with MSM from tilapia filleting residues in the acceptance test.
$53 \%$ of the samplers confirmed purchase intention of a tilapia mortadella with vegetal fat.

With regard to weight loss, averages of $12 \% \pm 1.0$ were found in the treatment 1 with the pasteurization method, while sausages subjected to hot smoking lost, on average, $24.5 \% \pm 0.8$ of weight. This difference was significant $(\mathrm{P}<0.05)$, since hot smoked sausages lost twice the amount of weight when compared with steam-pasteurized samples. Santos et al. (2007) observed a weight loss of $13.32 \%$ in smoked fillets, when compared with the same samples in natura. According to Sigurgisladottir et al. (2000), losses resulting from fish smoking can vary from 10 to $25 \%$, depending on the type of material in natura, the characteristics of the final product, and the parameters used in the process, such as time and temperature.

The averages obtained from water activity (Aw) were $0.97 \pm 0.002$ for smoked sausages and $0.98 \pm 0.002$ for pasteurized sausages. The first treatment presented a slightly lower but significantly different average $(\mathrm{P}<0.05)$, due to the reduced moisture content resulting from the process of hot smoking. Similar values were found by Oliveira Filho et al. (2010b) in tilapia sausages: the average water activity in their products was 0.98 .

Regarding instrumental texture, a significant difference $(\mathrm{P}<0.05)$ in hardness was detected among the products. The average for smoked sausages was $16.796 .0 \mathrm{~g} \pm 2.1$ whereas pasteurized sausages averaged $12.026 .0 \mathrm{~g} \pm 0.6$. A possible explanation lies in the fact that the lower moisture content observed in smoked sausages provided higher values of hardness when compared with pasteurized sausages. However, there were no differences for sensory texture between smoked and pasteurized sausages $(\mathrm{P}>0.05)$. Oliveira Filho et al. (2010b) obtained similar values for tilapia fillet sausages (13.1960 g). However, when the authors added tilapia MSM in the formulations, the hardness of the sausages decreased significantly, reaching $881.0 \mathrm{~g}$ with the addition of $100 \%$ MSM, and thus presenting a lower value when compared with the products formulated in this study.

During storage, luminosity values $\left(\mathrm{L}^{*}\right)$ remained virtually constant regardless of the type of packaging used (Figure 2). However, smoked sausages presented significantly lower values $(\mathrm{P}<0.05)$ (around 55.0 \pm 2.3 ) when compared with pasteurized sausages (66.0 2.6$)$. A similar result was observed by Choubert et al. (1992) with smoked rainbow trout fillets, for which the authors reported lower luminosity values due to the deposition of chemical compounds produced by the pyrolysis of wood.

The intensity of the red color $\left(\mathrm{a}^{*}\right)$ did not differ significantly $(\mathrm{P}>0.05)$ between pasteurized and smoked 
sausages, presenting initial values of $6.16 \pm 0.2$ for both treatments. This parameter remained constant during the storage period of smoked sausages, regardless of the packaging system used. However, pasteurized sausages showed significant differences $(\mathrm{P}<0.05)$ between packaging systems: a decrease in values of $\mathrm{a}^{*}$ for products packed in the conventional system was observed when compared with vacuum-packaged products (Figure 3 ).

The loss of intensity of red color may occur due to partial permeability of oxygen in conventional packaging. According to Olivo (2006), the incidence of oxygen during storage boosts the oxidation of lipids and pigments, causing changes in the color of the product. In the present study, the red color of the smoked sausages remained stable probably due to the smoking process, which gives color to the product, in addition to the antioxidant effect of the smoke.

The intensity of yellow color $\left(b^{*}\right)$ was similar between both treatments, with initial values around 13.0 (Figure 4). A significant increase $(\mathrm{P}<0.05)$ was observed on day 25 of storage of smoked sausages in conventional packaging.

Smoked sausages stored in vacuum-packaging did not present significant difference $(\mathrm{P}>0.05)$ between $\mathrm{b}^{*}$ values, despite showing a tendency to increase the intensity of the yellow color. Pasteurized sausages presented a significant difference $(\mathrm{P}<0.05)$ in $\mathrm{b}^{*}$ values over the days of storage, but demonstrated a tendency to remain stable. Oliveira Filho et al. (2010b) detected similar results in sausages made with $80 \%$ MSM from tilapia. The authors reported $b^{*}$ values around 12.0.

Regarding the microbiological analysis, no presence of Salmonella sp., coagulase-positive Staphylococcus or Escherichia coli was detected in stored sausages. Thus, all products elaborated in this study were in accordance with the Brazilian Legislation (Brasil, 2001).

The count of psychrotrophic aerobic microorganisms was very low in the treatment of smoked sausages, regardless of the packaging system or storage period (Table 3). Pasteurized sausages in both conventional and vacuumpackaging, however, presented high counts $(>7.0 \log \mathrm{cfu} / \mathrm{g}$

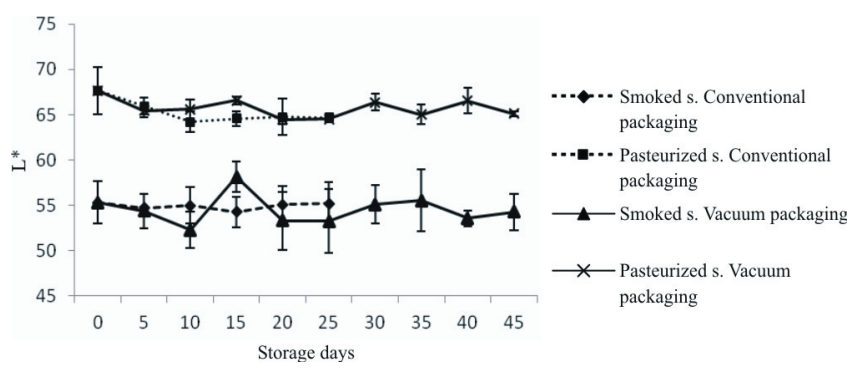

MSM - mechanically separated fish meat.

Figure 2 - Luminosity ( $\left.\mathrm{L}^{*}\right)$ of sausages made with MSM from filleting residues during storage at $5^{\circ} \mathrm{C}$.

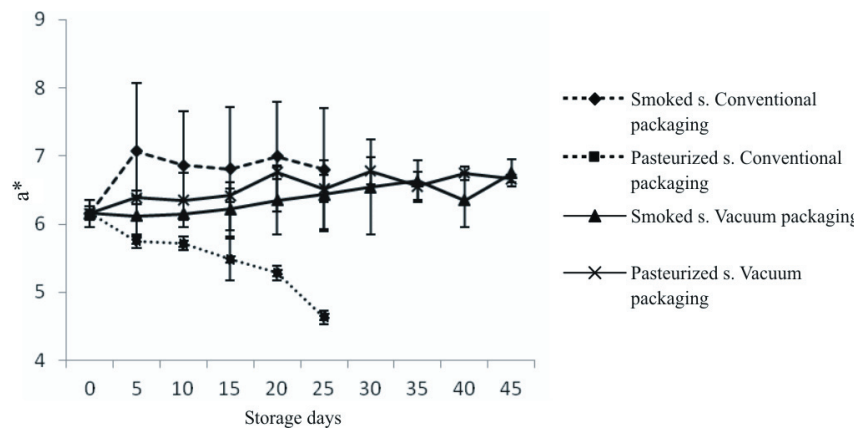

MSM - mechanically separated fish meat.

Figure 3 - Red-green color intensity ( $\left.\mathrm{a}^{*}\right)$ of sausages made with MSM from tilapia filleting residue during storage at $5{ }^{\circ} \mathrm{C}$.

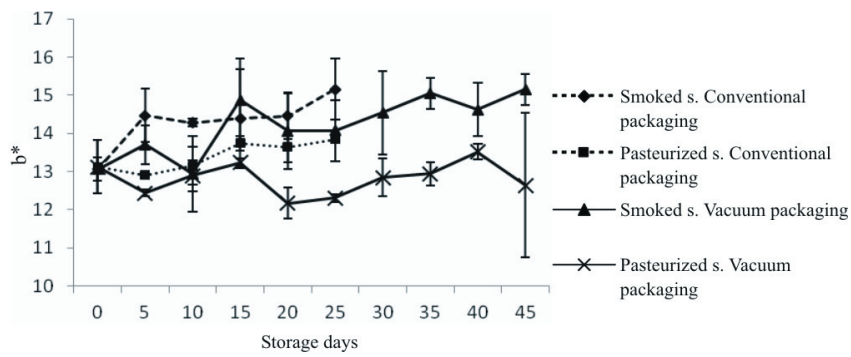

MSM - mechanically separated fish meat.

Figure 4 - Yellow-blue color intensity (b*) of sausages made with MSM from tilapia filleting residues during storage at $5{ }^{\circ} \mathrm{C}$.

Table 3 - Colony Forming Unit values (log cfu/g of sample) of psychrotrophic aerobic microorganisms in sausages made with MSM from tilapia filleting residue, during storage at $5{ }^{\circ} \mathrm{C}$

\begin{tabular}{|c|c|c|c|c|c|c|c|c|c|}
\hline \multirow{2}{*}{ Treatment } & \multicolumn{9}{|c|}{ Storage days } \\
\hline & 0 & 5 & 10 & 15 & 20 & 25 & 35 & 40 & 45 \\
\hline $\mathrm{SC}$ & $1 \mathrm{a}$ & $<1 \mathrm{~b}$ & $<1 \mathrm{~b}$ & $<1 \mathrm{~b}$ & $<1 \mathrm{~b}$ & $<1 \mathrm{~b}$ & nd & nd & nd \\
\hline $\mathrm{PC}$ & $2.48 \mathrm{e}$ & $5.74 d$ & $6.40 \mathrm{c}$ & $7 b$ & $7.95 \mathrm{a}$ & $8 a$ & nd & nd & nd \\
\hline SV & $1 \mathrm{~b}$ & $<1 \mathrm{c}$ & $<1 \mathrm{c}$ & $<1 \mathrm{c}$ & $<1 \mathrm{c}$ & $<1 \mathrm{c}$ & $2.18 \mathrm{a}$ & $<1 \mathrm{c}$ & $<1 \mathrm{c}$ \\
\hline PV & of & $3.3 \mathrm{e}$ & $5.6 \mathrm{~d}$ & $6.95 \mathrm{c}$ & $7.6 b$ & 7.98ab & $8.18 \mathrm{a}$ & $8.3 \mathrm{a}$ & $8.4 \mathrm{a}$ \\
\hline
\end{tabular}

MSM - mechanically separated fish meat; SC - smoked sausage in conventional packaging; PC - pasteurized sausage in conventional packaging; SV - smoked sausage in vacuum packaging; PV - pasteurized sausage in vacuum packaging.

nd - not determined.

All means from the same parameters located in the same rows, followed by lowercase letters, differ significantly according to the Tukey test ( $<<0.05)$. 
of sample) of psychrotrophic microorganisms on storage days 15 and 20, respectively.

The results demonstrated that the hot smoking method was an effective thermal process in the control of microorganisms, contributing to the microbiological stability of smoked sausages over the storage period.

Although there is no limit for the count of psychrotrophic aerobic microorganisms in the Brazilian Legislation, pasteurized sausages with a count equal or superior to $7.0 \mathrm{log} \mathrm{cfu} / \mathrm{g}$ are not recommended for consumption, since the degree of freshness and hygienicsanitary quality can be considered critical (ICMSF, 1986). Piccolo (2010) verified that mixed sausages, made with red meat and MSM from silver catfish filleting residues cooked at $72{ }^{\circ} \mathrm{C}$ and vacuum-packaged presented counts superior to $7.0 \mathrm{log} \mathrm{cfu} / \mathrm{g}$ of psychrotrophic aerobic microorganisms on storage day 42 at $5{ }^{\circ} \mathrm{C}$. Oliveira Filho et al. (2010a) observed $7.78 \mathrm{log} \mathrm{cfu} / \mathrm{g}$ psychrotrophic aerobic bacteria in sausages formulated with the addition of $80 \%$ MSM from tilapia filleting residues after 40 days of storage at $0{ }^{\circ} \mathrm{C}$, cooked at $72{ }^{\circ} \mathrm{C}$ for $1 \mathrm{~h} 20 \mathrm{~min}$. The authors did not detect the presence of Salmonella sp. or coagulase-positive Staphylococcus in sausages at days 5 and 40 of storage.

Regarding the $\mathrm{pH}$ values, the sausages remained below the maximum established limit for fish meat, which corresponds to 6.8 according to the Regulation for Industrial and Sanitary Inspection of Animal Products (RIISPOA) (Brasil, 1952). Although smoked sausages presented significantly different oscillations during the storage period $(\mathrm{P}<0.05)$, the $\mathrm{pH}$ averages remained around 6.0 (Figure 5). Fluctuations during this period do not cause significant variations in degradation processes, but must correlate with the biochemical, microbiological and sensory analyses (Cruz Casallas et al., 2012). From day 25 on, pasteurized, vacuum-packaged sausages presented a significant decrease in the $\mathrm{pH}$ value $(\mathrm{P}<0.05)$, averaging 5.5 at day 45 .

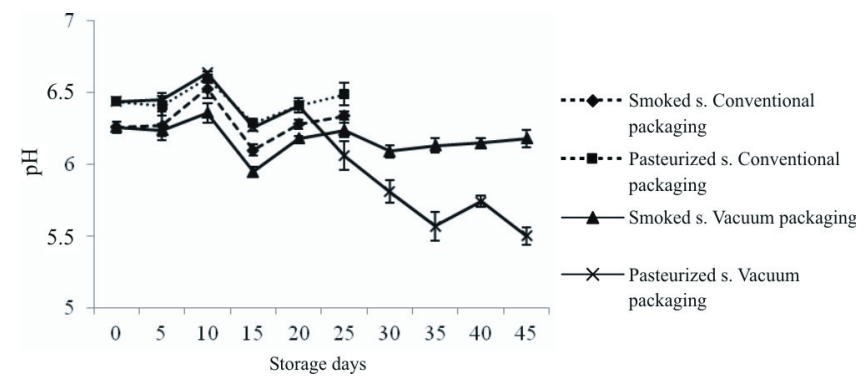

MSM - mechanically separated fish meat.

Figure 5 - $\mathrm{pH}$ of sausages made with MSM from tilapia filleting residues during storage at $5{ }^{\circ} \mathrm{C}$.
The decrease observed in $\mathrm{pH}$ values during refrigerated storage may be associated with acidification of the medium caused by lactic acid bacteria. These bacteria are psychrotrophic and generally found in embedded, vacuumpacked products stored under refrigeration (Silva et al., 2007). When comparing both treatments under the group that was vacuum-packaged, the decrease in $\mathrm{pH}$ values was higher in pasteurized sausages probably due to the lower efficiency of the pasteurization method in microbiological control when compared with smoking. The same $\mathrm{pH}$ reduction during storage was observed by Oliveira Filho et al. (2010a) in sausages made of MSM from tilapia, with a $\mathrm{pH}$ of 6.48 on day 5 and a $\mathrm{pH}$ of 6.27 on day 40 of storage.

Values for weight loss during storage of sausages in conventional packaging were significantly higher $(\mathrm{P}<0.05)$ when compared with sausages stored in vacuum packages. On the 25th day of storage, the weight losses of smoked and pasteurized sausages in conventional packaging were $5.0 \% \pm 0.2$ and $4.2 \% \pm 0.8$, respectively. At the end of storage, the weight losses for smoked and pasteurized sausages in vacuum packages were $1.0 \% \pm 0.4$ and $2.5 \% \pm 1.9$, respectively (Figure 6).

This was probably caused by the high permeability of PVC films, which enables water evaporation. Conversely, in vacuum-packaged sausages, the rate of oxygen and water vapor permeability is much lower, making this packaging system more efficient for weight control. However, the presence of a small amount of liquid exudate was observed in pasteurized, vacuum-packaged sausages. Similarly, Cardoso (2008) observed small losses by exudate (maximum of $1.8 \%$ ) in vacuum-packaged fish sausages stored at $2{ }^{\circ} \mathrm{C}$ for 55 days.

Alterations in TBARS values are associated with changes in the flavor and aroma of the product. Many compounds are formed during this process, e.g. hydroperoxides, which can, in turn, originate other compounds responsible for the appearance of a rancid odor and flavor in fish

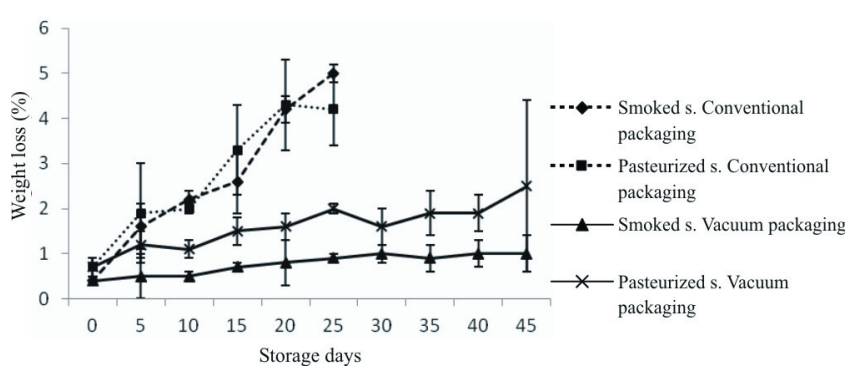

MSM - mechanically separated fish meat.

Figure 6 - Weight loss of sausages made with MSM from tilapia filleting residues during storage at $5^{\circ} \mathrm{C}$. 
oils (Yerlikaya et al., 2005). Sausages presented initial values of $1.35 \pm 0.1 \mathrm{mg}$ of malonaldehyde $/ \mathrm{kg}$. However, lipid oxidation values tended to increase until day 10 of storage. Vacuum-packaged sausages presented lower speed of oxidation over time, and the values tended to decrease from day 35 (Figure 7).

Thiobarbituric acid reactive substances (TBARS) values can decrease over the storage period due to reactions between malonaldehyde and proteins, turning these protein molecules into insoluble components. Consequently, secondary compounds resulting from lipid oxidation cannot be detected by the usual methods and TBARS values are relatively low (Ledward, 1981).

Yerlikaya et al. (2005) studied alterations in the quality of anchovy patties in conventional packaging stored at $4{ }^{\circ} \mathrm{C}$ for 6 days, observing higher TBARS values (10.61 to $27.21 \mathrm{mg}$ of malonaldehyde $/ \mathrm{kg}$ ) when compared with this study. Bilgin et al. (2008) detected significant differences in TBARS values of smoked, vacuum-packaged sea bream fillets during 60 days of storage, with an initial value of $1.02 \mathrm{mg}$ and final value of $2.5 \mathrm{mg}$ malonaldehyde $/ \mathrm{kg}$, with oscillations over the period. Silva et al. (2008) also observed a wide fluctuation of TBARS values during the six weeks of storage of smoked Blue catfish fillets (Ictalurus furcatus).

Although the Brazilian Legislation does not cite TBARS limit values for fish products, the maximum averages found in this study are similar to values cited by Balogun et al. (1984) and Al-Kahtani et al. (1996), who considered values below $3.32 \mathrm{mg}$ and $3 \mathrm{mg}$ malonaldehyde $/ \mathrm{kg}$ of sample, respectively, acceptable.

The thermal treatments used in this study significantly affected $(\mathrm{P}<0.05)$ the total volatile base nitrogen $(\mathrm{TVB}-\mathrm{N})$ values, and smoked sausages presented higher averages (Figure 8).

Bilgin et al. (2008) also noticed that the smoking process significantly increased $(\mathrm{P}<0.05)$ TVB-N values

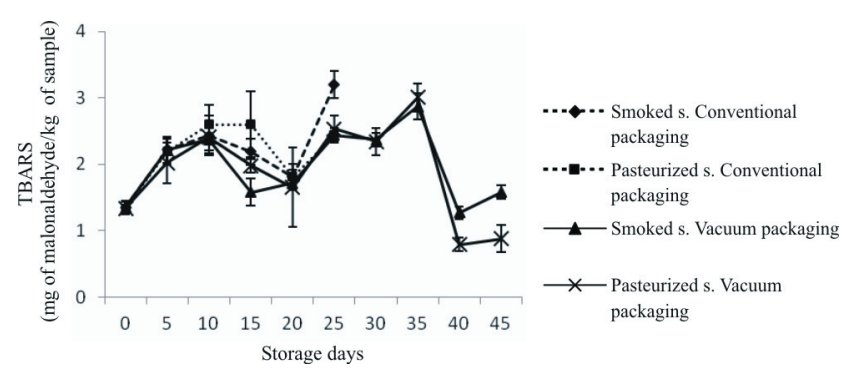

MSM - mechanically separated fish meat.

Figure 7 - Thiobarbituric acid reactive substances (TBARS) of sausages made with MSM from tilapia filleting residue during storage at $5{ }^{\circ} \mathrm{C}$.

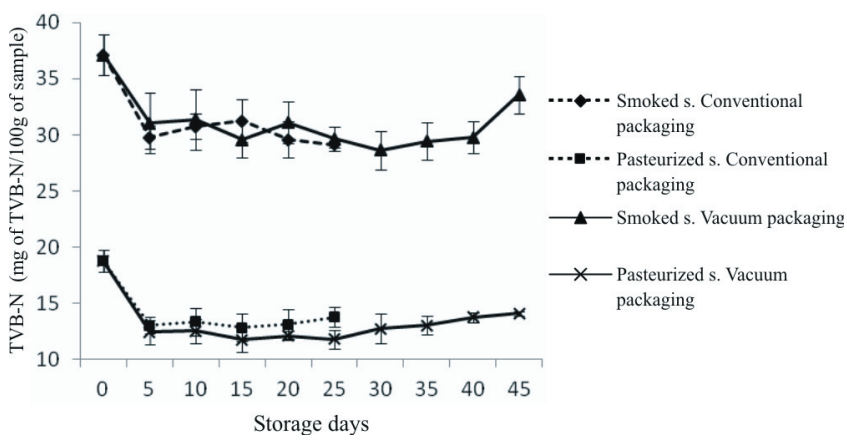

MSM - mechanically separated fish meat.

Figure 8 - Total volatile base nitrogen (TVB-N) of sausages made with MSM from tilapia filleting residues during storage at $5{ }^{\circ} \mathrm{C}$.

when compared with fish in natura. Sea bream fillets in natura presented $14.28 \mathrm{mg}$ TVB-N/100 g, while hot smoked fillets achieved $16.30 \mathrm{mg}$ TVB-N/100 g and cold smoked fillets presented values of $19.80 \mathrm{mg}$ TVB-N/100 g. Goulas \& Kontominas (2005) observed that TVB-N values of mackerel fillets almost doubled after the hot smoking process. Values of $11.28 \mathrm{mg}$ (TVB-N/100 g) for in natura fillets and $20.94 \mathrm{mg}$ (TVB-N/100 g) for smoked fillets were found.

Although there was a significant difference $(\mathrm{P}<0.05)$ between values over the storage period, they tended to stabilize. Similar results were observed by Travagin et al. (2009) in TVB-N quantification in tilapia fillets in natura conventionally and vacuum-packaged, during storage at $0{ }^{\circ} \mathrm{C}$ for 21 days: the authors did not detect any statistical difference between treatments. Fillets in conventional packaging presented values varying from 8.07 to $10.98 \mathrm{mg}$ of TVB-N/100 g during the storage period, whereas vacuumpackaged fillets exhibited values between $7.43 \mathrm{mg}$ and $9.67 \mathrm{mg}$ of TVB-N/100 g. However, Yerlikaya et al. (2005) found a progressive increase in total volatile base nitrogen in conventional packaged anchovy patties stored at $4{ }^{\circ} \mathrm{C}$ for 6 days. Similar results were reported by Bilgin et al. (2008) in sea bream fillet samples treated by hot smoking, vacuum-packaged and stored at $4{ }^{\circ} \mathrm{C}$.

The Brazilian law (BRASIL, 1997) establishes a limit of $30 \mathrm{mg}$ TVB-N/100 $\mathrm{g}$ for fresh fish. In this study, smoked sausages presented TVB-N values above the limit, which may be due to the smoking process. According to Fuentes et al. (2011), processed or semi-processed fish may present variations in TVB-N values, since the processing method can affect the TVB-N content in the final product. Therefore, high levels of TVB-N can be caused by the smoking process and not necessarily due to the product degradation. 


\section{Conclusions}

Mechanically separated fish meat (MSM) from Nile tilapia carcasses can be used in the formulation of fish sausages with good acceptance and high purchase and consumption intention. The smoking process, coupled to the use of vacuum packaging, can provide physical, chemical and microbiological stability to fish sausages. Sensory evaluation during storage time is recommended to confirm shelf life of the sausages as the values of TVB-N are influenced by smoking process.

\section{References}

AL-KAHTANI, H.A.; ABU-TARBOUSH, H.M.; BAJABER, A.S. Chemical changes after irradation and post-irradiation storage in tilapia and Spanish marckerel. Journal of Food Science, v.61, n.4, p.729-733, 1996.

ASSOCIATION OF OFFICIAL ANALYTICAL CHEMISTRY AOAC. Official methods of analysis. 17.ed. Washington: AOAC International, 2002.

BALOGUN, O.O.;AFOLABI, O.; IBIYEMI, S.A. etal. Malonaldehyde content of indigenous and imported foods and foodstuffs in Nigeria. Food Chemistry, v.14, n.3, p.157-165, 1984.

BİLGINN, F.; ÜNLÜSAYIN, M.; İZCI, L. et al. The determination of the shelf life and some nutritional components of gilthead seabream (Sparus aurata L., 1758) after cold and hot smoking. Turkish Journal of Veterinary and Animal Sciences, v.32, n.1, p.49-56, 2008.

BISCALCHIN-GRYSCHEK, S.F.; OETTERER, M.; GALLO, C.R. Characterization and frozen storage stability of minced Nile Tilapia (Oreochromis niloticus) and Red Tilapia (Oreochromis spp.). Journal of Aquatic Food Product Technology, v.12, n.3, p.57-69, 2003.

BOMBARDELLI, R.A.; SYPERRECK, M.A.; SANCHES, E.A. Situação atual e perspectivas para o consumo, processamento e agregação de valor ao pescado. Arquivos de Ciências Veterinárias e Zoologia da UNIPAR, v.8, n.2, p.181-195, 2005.

BORDIGNON, A.C.; SOUZA, B.E.; BOHNENBERGER, L. et al. Elaboração de croquete de tilápia do Nilo (Oreochromis niloticus) a partir de CMS e aparas do corte em "V" do filé e sua avaliação físico-química, microbiológica e sensorial. Acta Scientiarum Animal Sciences, v.32, n.1, p.109-116, 2010.

BOURNE, M. Food texture and viscosity: concept and measurement. 2.ed. New York: Academic Press, 2002. 427p.

BRASIL. Ministério da Agricultura, Pecuária e Abastecimento. Decreto n. 30.691, de 29 de março de 1952. Regulamento da inspeção industrial e sanitária de produtos de origem animal - RIISPOA. Diário Oficial da União, Brasília, DF, 7 de julho de 1952.

BRASIL. Ministério da Agricultura, Pecuária e Abastecimento. Portaria n. 185, de 13 de maio de 1997. Regulamento técnico de identidade e qualidade de peixe fresco (inteiro e eviscerado). Diário Oficial da União, Brasília, DF, 19 de maio de 1997.

BRASIL. Ministério da Saúde. Resolução n. 12, de 02 de janeiro de 2001. Regulamento técnico sobre os padrões microbiológicos para alimentos. Diário Oficial da União, Brasília, DF, 10 de janeiro de 2001.

BRASIL. Ministério da Agricultura, Pecuária e Abastecimento. Instrução Normativa n. 62, de 26 de agosto de 2003. Métodos analíticos oficiais para análises microbiológicas para controle de produtos de origem animal e água. Diário Oficial da União, Brasília, DF, 18 de setembro de 2003.
CARDOSO, C.; MENDES, R.; PEDRO, S. et al. Quality changes during storage of fish sausages containing dietary fiber. Journal of Aquatic Food Product Technology, v. 17, n.1, p.73-95, 2008.

CHOUBERT, G.; BLANC, J.M.; COURVALIN, C. Muscle carotenoid content and colour of farmed rainbow trout fed astaxanthin or canthaxanthin as affected by cooking and smoke-curing procedures. International Journal of Food Science and Technology, v.27, n.3, p. 277-284, 1992.

COMMISSION INTERNATIONALE DE L'ÉCLAIRAGE - CIE Colorimetry. 2.ed. Vienna: CIE Publication, 1986. 74p.

CRUZ CASALLAS, N.E.; CRUZ CASALLAS, P.E.; SUAREZ MAHECHA, H. Characterization of the nutritional quality of the meat in some species of catfish: a review. Revista Facultad Nacional de Agronomia - Medellín, v.65, n.2, p.6799-6809, 2012.

DUTCOSKY, S.D. Análise sensorial de alimentos. 3.ed. Curitiba: Champagnat, 2011. 426p.

FOGAÇA, F.H.S.; TRINCA,L. A.; BOMBO, A.J. et al. Optimization of the surimi production from Mechanically Recovered Fish Meat (MRFM) using Response Surface Methodology. Journal of Food Quality, v.36, n.3, p.209-216, 2013.

FUENTES, A.; FERNÁNDEZ-SEGOVIA, I.; BARAT, J. M. et al. Influence of sodium replacement and packaging on quality and shelf life of smoked sea bass (Dicentrarchus labrax L.). LWT Food Science and Technology, v.44, n.4, p.917-923, 2011

GOULAS, A.E.; KONTOMINAS, M.G. Effect of salting and smoking method on the keeping quality of chub mackerel (Scomber japonicus): biochemical and sensory attributes. Food Chemistry, v.93, n.3, p.511-520, 2005.

HOWGATE, P. Determination of total volatile bases. Aberdeen: Torry Research Station, 1976. TD 564, Appendix 4.

INTERNATIONAL COMMISSION ON MICROBIOLOGICAL SPECIFICATION FOR FOODS - ICMSF. Microorganisms in foods - Sampling for microbiological analysis: principles and specific applications. Toronto: University of Toronto Press, 1986. $193 p$.

LEDWARD, D.A. Intermediate moisture meats. In: LAWRIE, R.A. (Ed.) Developments in meat science. 2.ed. London: Elsevier Applied Science, 1981. p.159-194.

KIRSCHNIK, P.G.; MACEDO-VIEGAS, E.M. Efeito da lavagem e da adição de aditivos sobre a estabilidade de carne mecanicamente separada de tilápia faça Nilo (Oreochromis niloticus) durante estocagem a $-18^{\circ} \mathrm{C}$. Ciência e Tecnologia de Alimentos, v.29, n.1, p.200-206, 2009.

KIRSCHNIK, P.G.; VIEGAS, E.M.M.; PACHECO, M.T.B. Minced tilapia nuggets retain balanced amino acid profiles. Global Aquaculture Advocate, v.10, p.36-37, 2007.

KUBITZA, F. Tilápia: Tecnologia e planejamento na produção comercial. Jundiaí: Acqua Supre, 2000. 289p.

KUBITZA, F.; CAMPOS, J.L. O aproveitamento dos subprodutos do processamento de pescado. Panorama da Aquicultura, v.16, n.94, p.23-29, 2006

MARENGONI, N.G.; POZZA, M.S.S.; BRAGA, G.C. et al. Caracterização microbiológica, sensorial e centesimal de fishburgers de carne de tilápia mecanicamente separada. Revista Brasileira de Saúde e Produção Animal, v.10, n.1, p.168-176, 2009.

MELLO, S.C.R.P.; FREITAS, M.Q.; SÃO CLEMENTE, S.C. et al. Development and bacteriological, chemical and sensory characterization of fishburgers made of Tilapia minced meat and surimi. Arquivo Brasileiro de Medicina Veterinária e Zootecnia, v.64, n.5, p.1389-1397, 2012.

MINOZZO, M.G.; WASZCZYNSKYJ, N.; BEIRAO, L.H Características fisico-quimicas do patê de tilápia do Nilo (Oreochromis niloticus) comparado a produtos similares comerciais. Alimentos \& Nutrição, v.15, n.2, p.101-105, 2004.

MINOZZO, M.G.; WASZCZYNSKYJ, N.; BOSCOLO, W.R. Utilização de carne mecanicamente separada de tilápia (Oreochromis niloticus) para a produção de patês cremoso e pastoso. Alimentos e Nutrição, v.19, n.3, p.315-319, 2008. 
MOREIRA, R.T.; LEMOS, A.L.S.C.; HARADA, M.M. et al. Desenvolvimento e aceitação de embutido emulsionado tipo "mortadela" elaborado com tilápia (Oreochromis niloticus L.). Revista Higiene Alimentar, v.22, n.159, p.47-53, 2008.

NEIVA, C.R.P. [2006]. Aplicação da tecnologia de carne mecanicamente separada - CMS na indústria de pescado. In: SIMPÓSIO DE CONTROLE DO PESCADO, 2., 2006, São Paulo. Anais eletrônicos... São Paulo: Instituto da Pesca, 2006. Available at: $<\mathrm{ftp} / / \mathrm{ftp}$. sp.gov.br/ftppesca/IIsimcope/palestra_cristiane_neiva.pdf $>$. Accessed on: Feb 9, 2011.

OGAWA, M.; MAIA, E.L. Manual de pesca: ciência e tecnologia do pescado. 1.ed. São Paulo: Varela, 1999. 464p.

OLIVEIRA FILHO, P.R.C.; FÁVARO-TRINDADE， C.S.; TRINDADE, M.A. et al. Quality of sausage elaborated using minced Nile Tilapia submitted to cold storage. Scientia Agrícola, v.67, n.2, p.183-190, 2010a.

OLIVEIRA FILHO, P.R.C.; NETTO, F.M.; RAMOS, K.K. et al. Elaboration of sausage using minced fish of Nile tilapia filleting waste. Brazilian Archives of Biology and Technology, v.53, n.6, p.1383-1391, 2010b.

OLIVEIRA FILHO, P.R.C.; VIEGAS, E.M.M; KAMIMURA, E.S. et al. Evaluation of physicochemical and sensory properties of sausages made with washed and unwashed mince from Nile Tilapia by-products. Journal of Aquatic Food Product Technology, v.21, n.3, p.222-237, 2012.

OLIVO, R. Alterações oxidativas em produtos cárneos. In: SHIMOKOMAKI, M.; OLIVO, R.; TERRA, N.N. et al. (Eds.) Atualidades em ciência e tecnologia de carnes. São Paulo: Varela, 2006. p.155-163.

PARMIGIANI, P. O avanço dos industrializados suínos. Revista Nacional da Carne, v.34, n.398, p.88-93, 2010.

PICCOLO, J. Otimização de formulações de salsicha mista produzidas com carne de jundiá (Rhamdia quelen). 2010. 134f. Dissertação (Mestrado em Ciência e Tecnologia de Alimentos) Universidade Federal de Santa Maria, Santa Maria.

SANTOS, L.D.; ZARA, R.F.; VISENTAINER, J.V. et al. Avaliação sensorial e rendimento de filés defumados de tilápia (Oreochromis niloticus Linnaeus, 1757) na presença de alecrim (Rosmarinus officinalis). Ciência Agrotécnica, v.31, n.2, p.406-412, 2007.

SARY, C.; FRANCISCO, J.G.P.; DALLABONA, B.R. et al. Influência da lavagem da carne mecanicamente separada de tilápia sobre a composição e aceitação de seus produtos. Revista Acadêmica Ciências Agrárias e Ambientais, v.7, n.4, p.423-432, 2009.

SCORVO FILHO, J.D.; FRASCÁ-SCORVO, C.M.D.; ALVES, J.M.C. et al. A tilapicultura e seus insumos, relações econômicas. Revista Brasileira de Zootecnia, v.39, p.112-118, 2010.

SIGURGISLADOTTIR, S.; SIGURGISLADOTTIR, M.S.; TORRISSEN, O. Effects of different salting and smoking processes on the microstructure, the texture and yield of Atlantic salmon (Salmo salar) fillets. Food Research Internacional, v.33, n.10, p.847-855, 2000.

SILVA, F.V.; SARMENTO, N.L.A.F.; VIEIRA, J.S. et al. Características morfométricas, rendimentos de carcaça, filé, vísceras e resíduos em tilápias-do-nilo em diferentes faixas de peso. Revista Brasileira de Zootecnia, v.38, n.8, p.1407-1412, 2009.

SILVA, N.; JUNQUEIRA, V.C.A.; SILVEIRA, N.F.A. et al. Manual de métodos de análise microbiológica de alimentos. 3.ed. São Paulo: Varela, 2007. 536p.

SILVA, L.V.A.; PRINYAWIWATKUL, W.; KING, J.M. et al. Effect of preservatives on microbial safety and quality of smoked blue catfish (Ictalurus furcatus) steaks during room-temperature storage. Food Microbiology, v.25, n.8, p.958-963, 2008.

SOUZA, M.L.R.;BACCARIN,A.E.;VIEGAS, E.M.M. etal.Defumação da tilápia do Nilo (Oreochromis niloticus) inteira eviscerada e filé: aspectos referentes às características organolépticas, composição centesimal e perdas ocorridas no processamento. Revista Brasileira de Zootecnia, v.33, n.1, p.27-36, 2004.

TRAVAGIN, L.G.F.; JULIÃO, L.; MENEGAZZO, T.M. et al. Avaliação das bases nitrogenadas voláteis totais e $\mathrm{pH}$ como indicadores de frescor em filés de Tilápia do Nilo (Oreochromis niloticus) minimamente processados armazenados em diferentes embalagens e sob refrigeração. In: SIMPÓSIO INTERNACIONAL DE INICIAÇÃO CIENTÍFICA DA USP, 17., 2009, São Paulo. Anais... São Paulo: Universidade de São Paulo, 2009. (CD-ROM).

VYNCKE, W. Direct determination of the thiobarbituric acid value in trichloroacetic extracts of fish as a measure of oxidative rancidity. Fette-Seinfen Anstrichmittel, v.72, n.12, p.1084-1087, 1970.

YERLIKAYA, P.; GOKOGLU, N.; URAN, H. Quality changes of fish patties produced from anchovy during refrigerated storage. European Food Research Technology, v.220, n.3-4, p.287-291, 2005. 